\title{
Multiple breccia events in the lower part of the Carboniferous Windsor Group, Nova Scotia*
}

\author{
D. Lavoie' ${ }^{1}$ D.F. Sangster ${ }^{2}$, M.M. Savard ${ }^{1}$, and F. Fallara ${ }^{1}$ \\ Geological Survey of Canada \\ ${ }^{1}$ Centre Géoscientifique de Québec, P.O. Box 7500, Ste-Foy, Quebec G1V 4C7, Canada \\ 2Mineral Resources Division, Ottawa, Ontario, Canada
}

Date Received May 3, 1995

Date Accepted August 14, 1995

\begin{abstract}
Base metal occurrences in the Carboniferous Windsor Group are commonly associated with carbonate breccias of which three types are recognized: one synsedimentary, one tectonic and one post-burial karstic. The synsedimentary type occurs in the Macumber Formation and in the so-called Pembroke siderite (Walton area); sedimentologic and diagenetic elements indicate rotational slides on a deep-water slope. The tectonic breccia occurs along the top of the Macumber Formation and is a manifestation of the Ainslie Detachment, a flat-lying extensional fault. Finally, what is referred to as the Pembroke breccia consists of irregularly distributed, post-burial, post-tectonic, postmineralization, karstic, solution-collapse breccia. The synsedimentary and tectonic breccias are either pre- or synore, although, both have played a key role in localizing mineral deposition through enhanced permeability, as exemplified by the Jubilee and Walton deposits.
\end{abstract}

Les minéralisations métallifères dans le Groupe de Windsor (Carbonifère) sont généralement associées à des brèches à carbonates desquelles trois types sont reconnues: l'une synsédimentaire, une tectonique et une postenfouissement karstique. La brèche synsédimentaire est présente dans la Formation de Macumber et dans l'unité connue comme la Sidérite de Pembroke (région de Walton); les éléments sédimentologiques et diagénétiques suggèrent des glissements rotationels sur une pente en eau profonde. Une brèche tectonique est présente au sommet de la Formation de Macumber, elle est la manifestation du Détachement d'Ainslie, une faille extensionnelle subhorizontale. Finalement, ce qui est désigné comme la brèche de Pembroke consiste en une brèche karstique d'effondrement par solution, laquelle est post-enfouissement, post-tectonisme, post-minéralisation et à distribution très irrégulière. Les brèches synsédimentaires et tectoniques sont soit pré- ou syn-minéralisation, cependant, ces deux dernières ont joué un rôle crucial dans la localisation des dépôts minéralisés en augmentant la perméabilité des unités, comme illustré par les dépôts de Jubilee et de Walton.

\section{INTRODUCTION}

The Viséan Macumber (Weeks, 1948) and the locally overlying Pembroke (Weeks, 1948) formations of the Windsor Group, with the laterally equivalent Gays River Formation, represent the first significant marine carbonate units in the post-Acadian successor Magdalen Basin (Fig. 1). These units constitute the base of the first of five transgressive-regressive cycles of the Windsor Group (Giles, 1981).

Of critical metallogenic importance for the lower part of the Windsor Group is the local presence of abundant carbonate breccias. The intimate association between base metal mineralization and breccia has long been known for this part of the Windsor Group, but the origin of these breccias has been the subject of much debate. Although some of these breccias are significantly different in many aspects, over the years, most of them have been correlated with the Pembroke. Moreover, the term Pembroke is also used by mining company geologists to designate, in drill cores from the Walton area, a mound-shaped, massive and mottled sideritized unit overlying the sideritized laminated material of the Macumber
Formation. Consequently, this has led to confusion and contradictions, not only in the description and distribution of the Pembroke, but also with regards to proposed brecciation processes. As a consequence, primary sedimentary (Sage, 1954; Stevenson, 1958; Schenk, 1967), diagenetic (Clifton, 1967; Geldsetzer, 1977, 1978; Smith and Collins, 1979) and tectonic (Giles and Lynch, 1994; Fallara et al., 1994) brecciation mechanisms have been put forward for various basal Windsor breccias. On the other hand, only a few reports have discussed possible multiple origins for the breccias (Hein et al., 1993; Lavoie, 1994; Lavoie and Sangster, 1995).

This contribution presents outcrop, drill core, and petrographic data related to the breccia problem. It is proposed that the basal Windsor carbonate breccias are the result of several processes acting at different times; during sedimentation, burial and finally after uplift of the succession. Criteria for distinguishing between the various types and stages of brecciation are presented. A brief outline of the relationships between breccias and mineralizations for the Jubilee and Walton deposits will show the metallogenic significance of these distinctions; more comprehensive studies on these

* Geological Survey of Canada Contribution Number 13795.

Atlantic Geology

31, 197-207 (1995) 


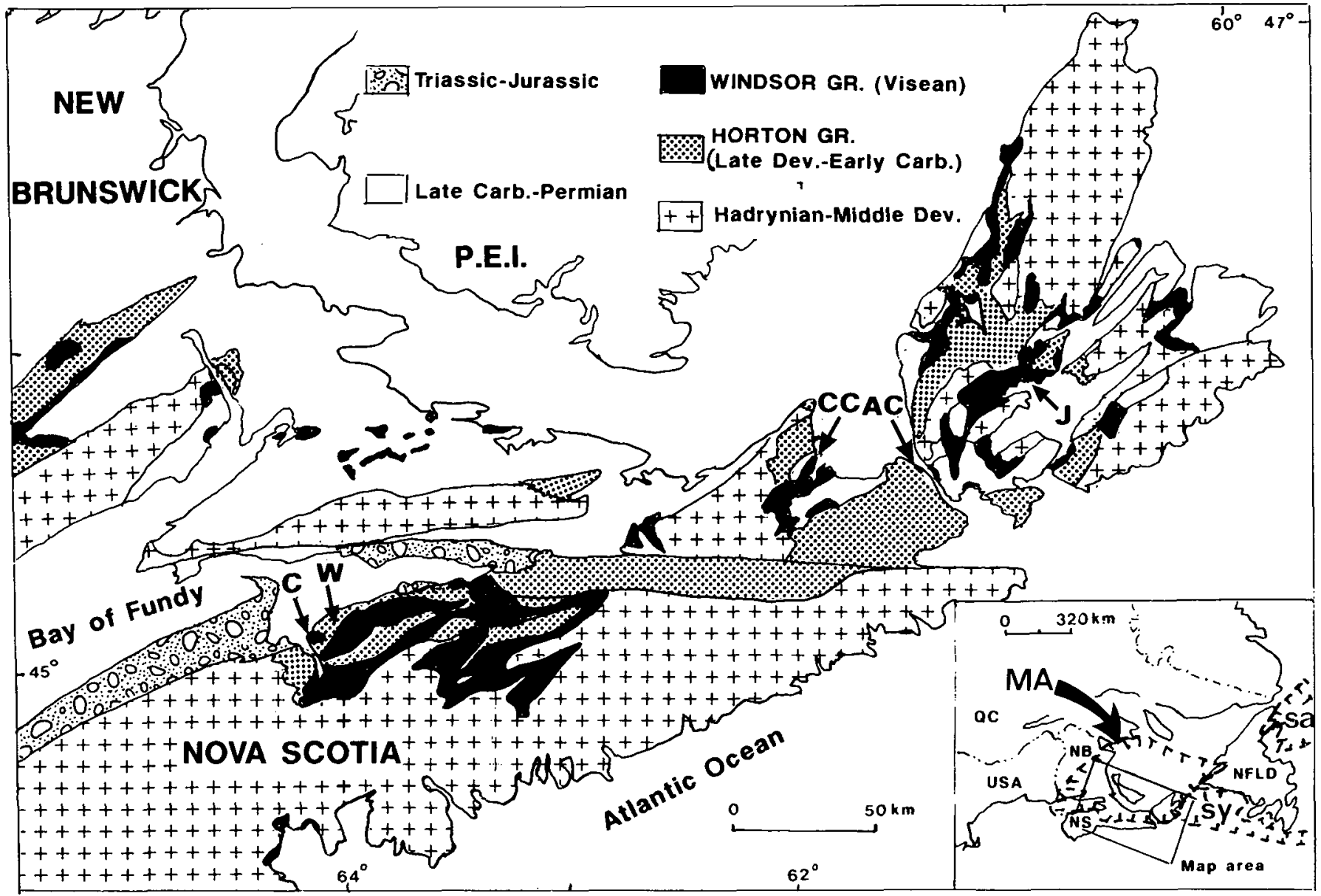

Fig. 1. Simplified geology and location of basal Windsor carbonate breccias. AC is for Aulds Cove, CC is for Crystal Cliffs (Antigonish area), $\mathrm{C}$ is for Cheverie, $\mathrm{W}$ is for Walton, $\mathrm{J}$ is for Jubilee. The inset locates the Magdalen Basin (MA), sa is for Saint-Anthony basin and sy is for Sydney basin. Modified from Boehner et al. (1989).

deposits are available elsewhere (Basal Windsor Working Group, 1994; Fallara, 1995; Burtt, 1995), and integration of all the pertinent data is currently in progress.

\section{GEOLOGIC, STRATIGRAPHIC AND SEDIMENTOLOGIC SETTINGS}

The Lower Carboniferous Windsor Group outcrops in many structural sub-basins of the Magdalen Basin (Fig. 1), a successor basin initiated by extensional collapse of the Acadian orogen in Late Devonian time (Lynch and Tremblay, 1994). A thick Hadrynian - Middle Devonian succession constitutes the basement to the successor basin. The Windsor Group overlies either conformably to paraconformably the Upper Devonian - lowermost Carboniferous Horton Group, or unconformably the Cambrian-Ordovician Meguma Group (Fig. 2). The Windsor Group is, in turn, conformably to unconformably overlain by a thick succession of Carboniferous to Jurassic siliciclastics (Fig. 2). The Windsor Group contains almost exclusively the only marine record of the Magdalen Basin (Giles, 1981). Its stratigraphy is dominated by siliciclastics and evaporites; only a minor part consists of carbonates (Giles, 1981).
At the base of the Windsor Group (Fig. 2), the Macumber Formation occurs basin-wide. It overlies the Horton Group, a continental unit deposited in post-orogenic distensive basins (Hamblin and Rust, 1989), whereas the laterally equivalent Gays River reefoid mounds unconformably overly the metawackes of the Meguma Group or other pre-Carboniferous basement rocks. The so-called "transition beds" between Macumber and Gays River lithofacies are dominated by Macumber-like lithologies (e.g., deep-water laminites, slumps) unconformably overlying Meguma lithologies.

Research addressing the breccia problem needs to deal with the origin of the Macumber Formation, because some of the breccias assigned to the Pembroke (e.g., Walton area) are also embedded within the Macumber. Over the years, different interpretations for the proposed paleoenvironmental significance of the Macumber Formation have arisen. The upper two-thirds of the Macumber are typified by a subcentimetric planar fabric developed in limestones. These limestones were regarded either as intertidal algal mats (Schenk, 1967), as deep-water microbial laminites (Geldsetzer, 1978; Giles, 1981; Hein et al., 1993; Schenk et al., 1994; Lavoie and Sangster, 1995), as deep-water methane-vent bioaccumulations (von Bitter et al., 1992), as lacustrine deposits 


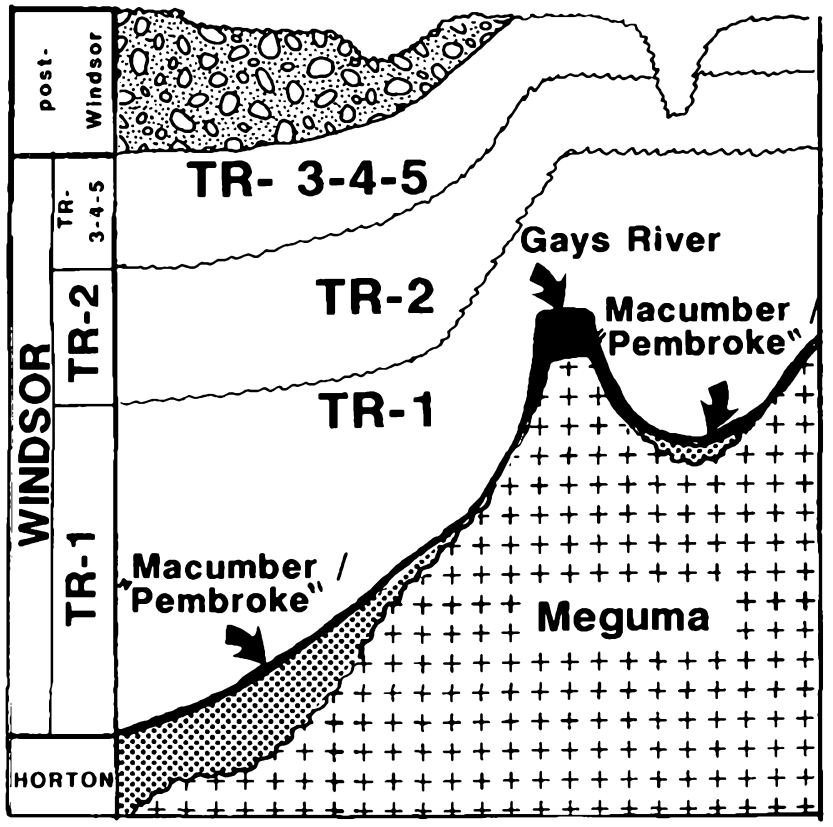

Fig. 2. Major transgressive-regressive (T-R) cycles in the Windsor Group and stratigraphic position of the Macumber-"Pembroke" succession. Modified from Giles (1981).

(Schenk et al., 1992), and have been proposed to include calc-mylonites (Lynch and Giles, 1993; Lavoie, 1994; Lynch and Tremblay, 1994).

The Macumber is divided into two lithostromes (Lavoie, 1994; Lavoie and Sangster, 1995; Lavoie and Savard, 1995), which approximately correspond to lithosomes A and B of Schenk (1967), recently interpreted to represent formation and euxinic stages of basin evolution by Schenk et al. (1994). The lower unit consists of lime mudstone and wackestone/ packstone beds, the latter being characterized by restricted fauna (mostly ostracodes), burrowers (Planolites-like), abundant peloids, micrite intraclasts, grapestones and oolites. The coarsergrained lithofacies display sedimentary structures (scours, gradings and rare, low-angle cross laminations) indicative of higher-energy, storm-related events in a dominantly, lowenergy, below fairweather-wave base setting (Fig. 3a). The upper lithostrome consists of the platy lithofacies (Fig. 3b) in which deep-water microbial mats are recognized by the presence of plane-bedded aligned peloids with poorly preserved calcimicrobes. At the bottom of the upper lithostrome, these mats are interbedded with the coarser-grained lithofacies whereas, higher up, interbeds of lime mudstone are seen (Fig. 3b). Moreover, burrows cutting through the mats are filled with peloidal/bioclastic limestone suggesting that microbial-dominated sedimentation occurred downslope from the coarse-grained carbonates. Therefore, the microbial mats are likely indicative of a below storm wave base setting. The uppermost part of the Macumber is characterized by interbedded microbial mats and sulphate pseudomorphs suggesting increasing hypersalinity in a deep water setting leading to sulphate precipitation. As a whole, the Macumber For-
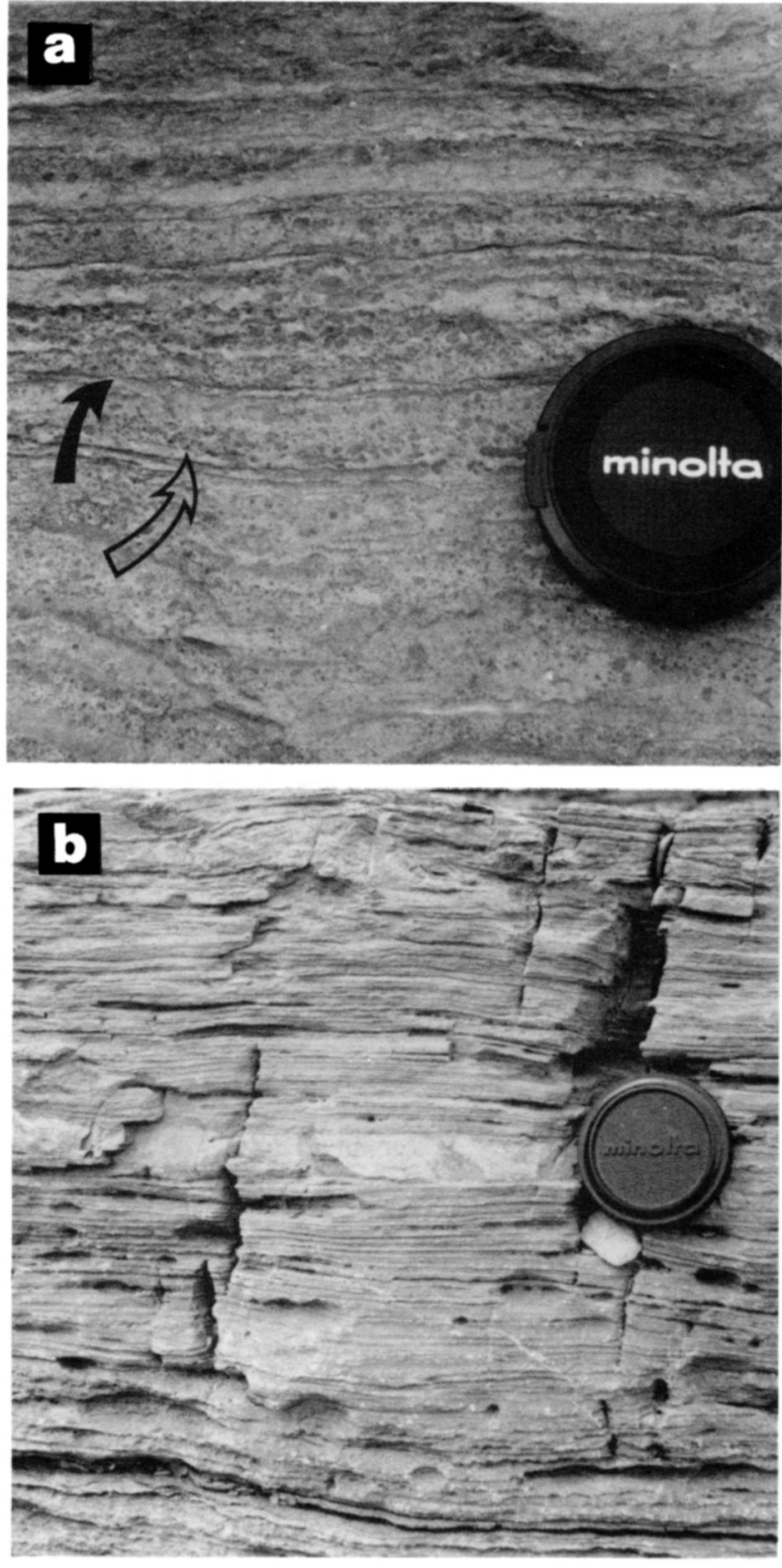

Fig. 3. (a) Cross-section view of centimetre-thick laminae of intraclastic - peloidal packstone and wackestone. Normal-graded lamina (open arrow) is overlain by inverse-graded lamina (black arrow), Aulds Cove area. (b) Typical planar lithofacies of the Macumber Formation with an interbed of massive micrite, Aulds Cove area.

mation represents a deepening-upward succession following a rapid and major flooding event (Giles, 1981; Lavoie and Sangster, 1995; Lavoie and Savard, 1995).

Undifferentiated, basal Windsor carbonate breccias are found in the upper part of the second lithostrome or directly overly it. From outcrops and drill cores, these breccias have been studied in mainland Nova Scotia (Walton, Cheverie, Antigonish and Aulds Cove areas) and Cape Breton Island (Jubilee area) (Fig. 1). 


\section{Basal Windsor carbonate breccias}

\section{The Macumber breccias}

\section{Synsedimentary slump breccia}

This breccia occurs in centimetre- to decimetre-thick intervals (Fig. 4a). It has been found in the Macumber Formation (Cheverie and Walton areas, Fig. 1) and in the "transition beds" (Schenk et al., 1994; Lavoie and Sangster, 1995). This breccia constitutes one of the dominant rock types in the socalled Pembroke mound-shaped, siderite unit of the Walton area (Lavoie and Sangster, 1995).
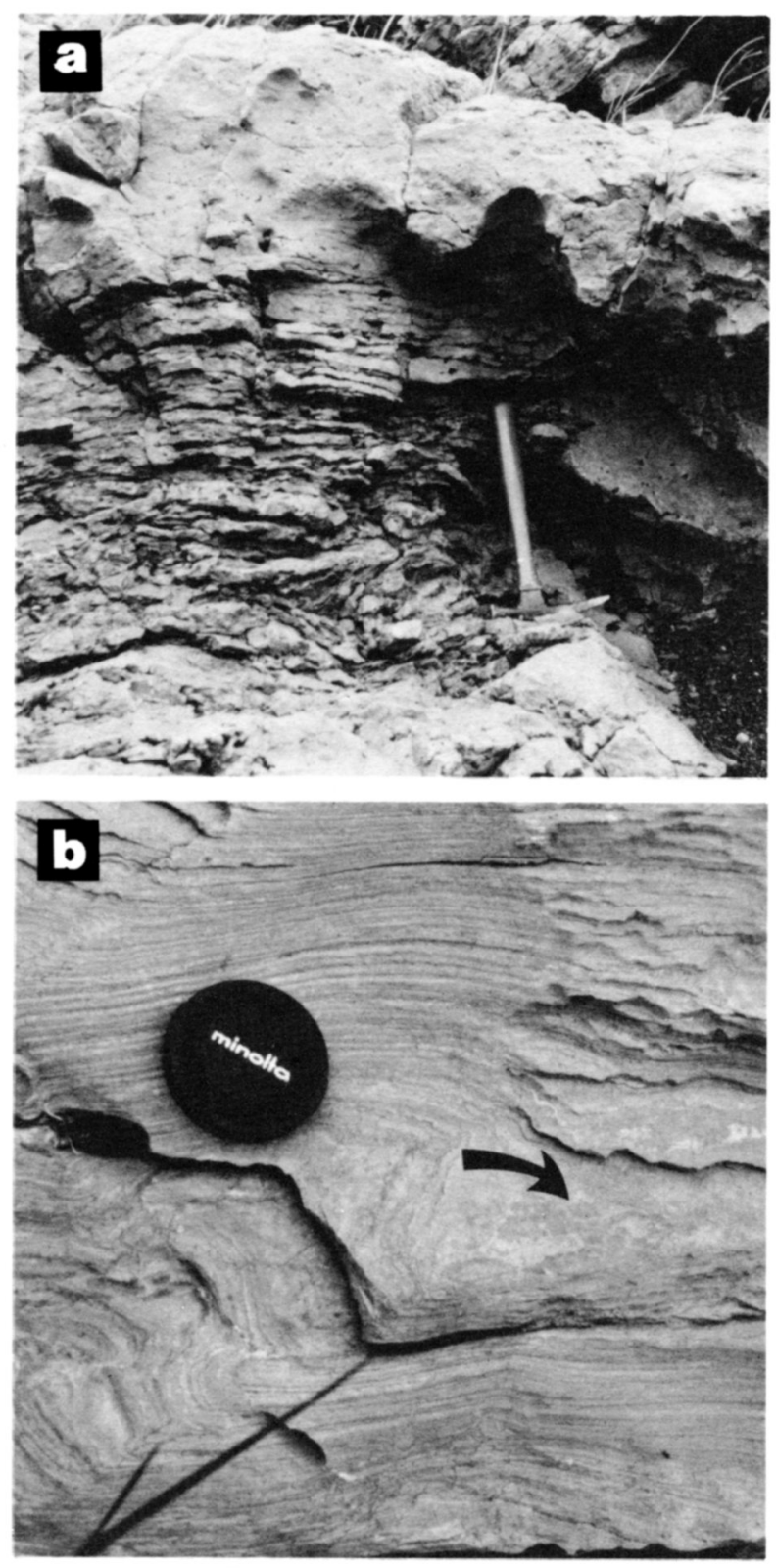

Fig. 4. (a) Synsedimentary slump breccia within the Macumber Formation. Note the concave, shear failure plane cutting through the underlying beds, Cheverie area. (b) Slump fold developed in the microbial laminites. Note the local microbrecciation (arrow), Crystal Cliff area.
As seen in most drill cores (Macumber Formation and Pembroke siderite) and some field sections (Macumber Formation and "transition beds"), the breccia occurs in a predictive cyclic pattern. The succession forms decimetre- to metre-thick intervals made up of initial well-bedded and undeformed microbial mats passing upward into a zone of crenulated and contorted mats with centimetre-thick slump folds (Fig. 4b), grading into breccia which is overlain either by mildly or undeformed mats (Fig. 5). From the limited view available in drill cores, the contacts between these zones are fairly conformable; however, outcrops show that the breccia may truncate beds (Fig. 4a).

The breccia is clast-supported with fragments averaging more than $80 \%$ of the breccia volume. The fragments are chaotically distributed with no granulometric trend. The clasts consist solely of microbial mats; some of these show soft sediment deformation structures cut at the clast margins. The fragments are usually small, ranging in size from less than $1 \mathrm{~mm}$ to a maximum of $10 \mathrm{~cm}$ (average of $2 \mathrm{~cm}$ ). They are, owing to the nature of the brecciated lithofacies, elongated in shape although no imbrication of the clasts was noted; some fragments show rounded to sub-rounded margins (Fig. 6a) suggesting transport or remobilisation processes. The matrix of the breccia is made up of fine grained carbonate material composed of a mixture of minute fragments identical to the larger clasts and of lime mud (Fig. $6 \mathrm{~b})$. For the Pembroke siderite of the Walton area, brecciation pre-dated sideritization of carbonates and precipitation of siderite in voids; abundant barite replaced siderite (Burtt, 1995).
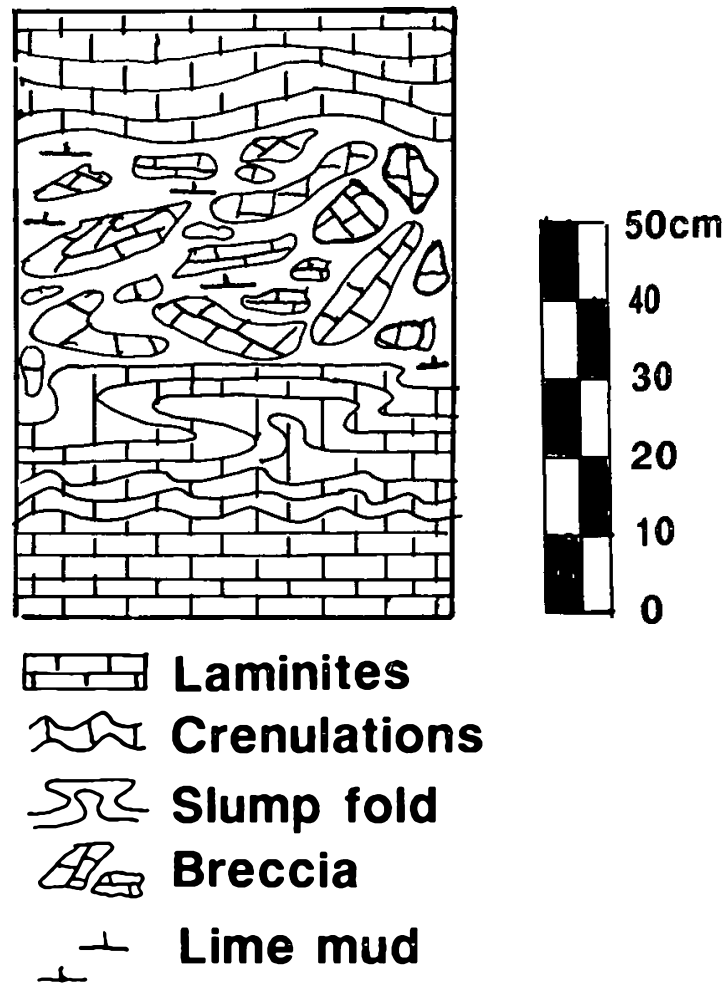

Fig. 5. Schematic illustration of the repetitive rock succession that hosts the synsedimentary breccia for both the Macumber Formation and the "Pembroke siderite". 

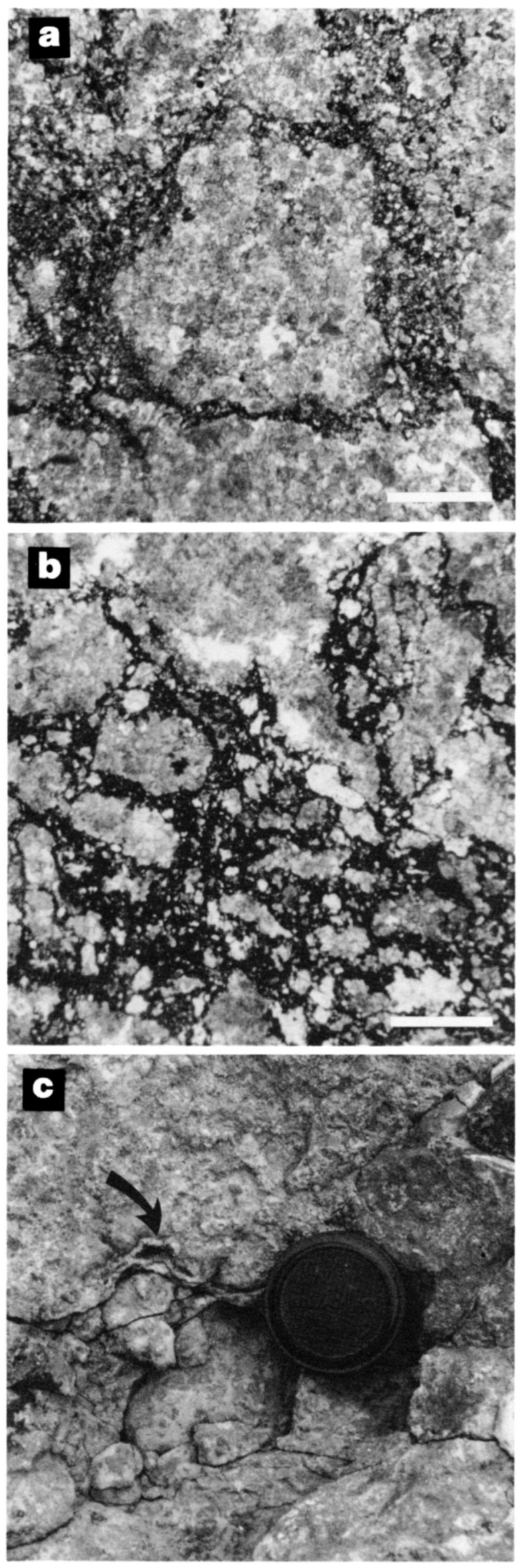

Diagenetic features of the breccia are significant to its origin. Stylolites are continuous through the matrix and fragments, suggesting that the breccia was formed prior to significant burial. Secondary dissolution porosity, with centimetresized pores filled with anhedral calcite and solid bitumen, cuts both clast and matrix (Fig. 6c). This suggests that the breccia was formed not only prior to significant burial but also before hydrocarbon migration.

The overall evidence argues for a synsedimentary formation of the breccia. Below wave base rotational slides resulting from extreme soft sediment deformation and slope failure are the likely causes of the breccia (Lavoie and Sangster, 1995). This interpretation is based on: (1) the presence of discrete, concave shear failure planes, (2) the lack of fairweatheror storm-induced sedimentary structures, (3) the presence of a fine grained matrix in part derived from background suspension sedimentation, (4) the rounding of some clast margins due to remobilisation caused by gravity-driven movement of disrupted beds, (5) the chaotic nature of softsediment deformation within a cycle, and (6) the preferred association with the Macumber platy lithofacies, that is deepwater microbial mats. All the previous evidence, besides the interpretation of the Macumber environment of deposition itself, are common to modern and ancient slope breccias (see Cook and Mullins, 1983). Deep-water slump domes have recently been documented in the Macumber Formation (Schenk et al., 1994; Tobey et al., 1995).

\section{Late tectonic breccia}

Some breccias in the uppermost part of the Macumber are related to a post-Windsor, bedding-parallel extensional shear. Recognition of this event is supported by the local absence of various parts of the Windsor Group immediately above the Macumber Formation (Giles et al., 1995). These features led to the proposal of the Ainslie Detachment, positioned at the Macumber / evaporite interface (Lynch and Giles, 1993; Lynch and Tremblay, 1994; Savard et al., in press). A tectonic origin for the breccias occurring at this stratigraphic position has consequently been proposed (Paradis et al., 1993; Giles and Lynch, 1994; Fallara et al., 1994; Lavoie and Sangster, 1995).

This late tectonic breccia is best exposed at Crystal Cliffs and Aulds Cove (Fig. 1) and in cores of the Jubilee deposit. At Aulds Cove, the Macumber Formation is abruptly overlain by the upper Viséan - Namurian Mabou Group; from

Fig. 6. (a) Photomicrograph (plane-polarized light) of the synsedimentary breccia showing the unsorted fabric and some rounding of clast margins. Scale bar is $1 \mathrm{~mm}$. Sample from Walton area. (b) Photomicrograph (plane-polarized light) illustrating the relative timing of sideritization and brecciation and the matrix of the breccia, that is small carbonate fragments and lime mud. All fragments are entirely sideritized with siderite crystals extending out on fragments. Scale bar is $1 \mathrm{~mm}$. Sample from Walton area. (c) Dissolution pore (arrow) cutting through both clasts and matrix of the synsedimentary breccia. The void is filled with initial calcite cement and late solid bitumen. Cheverie area. 
regional stratigraphy, close to $1500 \mathrm{~m}$ of Windsor Group strata are missing (Giles and Lynch, 1994). Immediately underlying the Mabou, 2 to $3 \mathrm{~m}$ of light-brown, recrystallized calc-mylonite is observed containing abundant, recumbent, detached isoclinal folds; this is underlain by $30 \mathrm{~cm}$ of highly brecciated Macumber material (Fig. 7a). It is tempting to relate this breccia to either a lag deposit overlying a major unconformity or a solution collapse breccia. However, this breccia lacks the polymictic nature of clasts that should typify the latter and the sedimentary/diagenetic characteristics expected from the former (see Savard et al., in press).

The tectonic breccia is cement- to locally clast-supported, with clasts reaching about 40 to $75 \%$ of the total rock-volume. The clasts are chaotically distributed and no sedimentary structures are visible. The fragments are composed of the platy lithofacies of the Macumber, they are elongated to equigranular in shape and show angular-only margins. Fragments have locally a jigsaw puzzle texture suggesting that, in some cases, displacement was not significant (Fig. 7b). Stylolites terminate at clast margins. The breccia fragments are cemented by sparite with some barite in the Walton area. Locally, a hydrocarbon-rich, coarse, fibrous cement forming isopachous crusts, coats fragments, suggesting that this peculiar cement is post-brecciation and of burial origin (Fig. 7c); at the Jubilee deposit, the mineralization event postdates this cement.

The breccia offers good evidence for a late origin (following some burial) and is explained by tectono-hydraulicfracturing and rapid cementation of fragments (Lavoie and Sangster, 1995). The presence of this breccia underlying the Mabou Group at Aulds Cove (Giles and Lynch, 1994) and in the upper part of the Windsor Group at Jubilee (Fallara et al., 1994; Savard et al., in press), argues for tectonic activity along the Ainslie Detachment zone which passes through these locations. Moreover, the uppermost beds of the Macumber Formation at Port Hasting (6 km southeast of Aulds Cove) show clear evidence of tectonic overprinting (sigmoidal calcite fibres associated with stretched peloids; Lavoie and Sangster, 1995).

\section{The Pembroke unit}

The term Pembroke Formation was introduced by Weeks (1948) to designate an assemblage of limestone conglomerates and red calcareous siliciclastics overlying the Macumber Formation in the type area near Walton. Clifton (1967) proposed to abandon the name Pembroke Formation, since it had been preempted for a Silurian volcano-sedimentary unit in Maine (Bastin and Williams, 1914). Therefore, the term

Fig. 7. (a) Partly brecciated calc-mylonite (upper unit) and brecciated Macumber Formation (lower unit) near the top of the Macumber Formation at Aulds Cove. (b) Photomicrograph (plane-polarized light) showing the puzzle-like texture of fragments suggestive of rapid cementation of the breccia. Scale bar is $1 \mathrm{~mm}$. Sample from Aulds Cove. (c) Photograph of a rock slab illustrating the isopachous fabric of early cement around a clast at the Jubilee deposit.
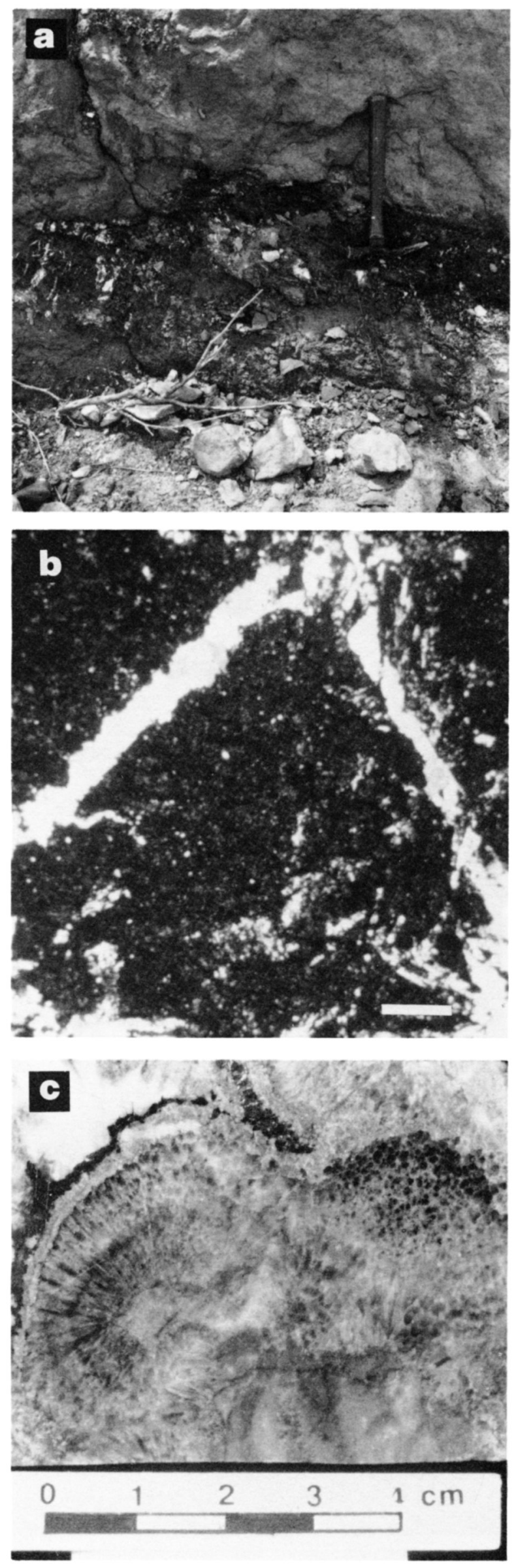
Pembroke is used informally, and because there is considerable confusion regarding its meaning, we suggest restricting it to a late karstic breccia for which the description follows.

\section{Late karstic breccia}

From outcrops and drill cores, the late karstic breccia has an erratic distribution. When present, it may incorporate the other two breccias described above or affect only the non-brecciated Macumber microbial mats. Its best exposures are at Cheverie, Crystal Cliffs and from cores of the Walton deposit (Fig. 1).

The Pembroke breccia ranges in thickness from less than a few centimetres (drill cores from the Walton area) up to about $3 \mathrm{~m}$ (drill cores and outcrops). The breccia is usually clast-supported but matrix-supported intervals are commonly present. Fining- and coarsening-upward trends are locally developed over metric intervals, although these trends are not correlatable between even closely spaced drill holes. The clasts can reach $50 \mathrm{~cm}$ in size but the average dimension is usually centimetric (Fig. 8a).

This breccia is polymictic in nature; the largest and dominant clasts are from the Macumber platy lithostrome (Fig. 8a). They are irregular in shape with angular margins suggesting a local origin. Many of these clasts are characterized by oxidized rims and surface dissolutions (Fig. 8b). Fragments of the synsedimentary breccia (Fig. 8c) and, in the Walton area, of pre-ore sideritized carbonates, are also found; the combined evidence supports a late origin for the Pembroke breccia. Besides carbonate fragments, up to $25 \%$ red mudstone clasts are present throughout the breccia. These are small in size (less than $4 \mathrm{~cm}$ ), elongated to equigranular and have rounded margins, suggesting some significant remobilisation. Finally, a few small clasts of evaporites are observed in drill cores from the Walton area. The matrix of the breccia consists of millimetre-sized, locally graded, limestone fragments with subordinate lime mud (Fig. 8d). Moreover, centimetre- to metre-sized pockets of cross-stratified and locally graded, reddish calcareous siltstones and fine grained sandstones (Fig. 8a) are found in the breccia. Isopachous and gravitational calcite crusts locally line cavity walls and either precede or postdate internal sediments (Fig. 8e). These crusts consist of calcite crystals clearly different from the fibrous calcite crystals of the tectonic breccia at Jubilee; under cathodoluminescence, the latter is uniformly bright luminescent, the former consists of alternating non-luminescent, dull and bright luminescent fine zones. The isopachous cement crusts are found with either the siliciclastic or the fine grained carbonate fills.

The Pembroke breccia is interpreted as a collapse breccia, resulting from the solution of the interbedded limestoneevaporite succession at the top of the Macumber Formation when this stratigraphic interval was exposed and open to the influx of exogenic fragments. This hypothesis is based on the following evidence: (1) dissolution features are visible on the surface of many limestones clasts; (2) oxidized rims typify many carbonate fragments; (3) variable sedimentary trends (coarsening- and fining-upward) are common in karst porosity; (4) the carbonate matrix is commonly reddish due to oxidation; (5) the difference in rounding of fragments suggests local derivation of angular carbonate fragments and remobilisation of siliciclastic fragments from higher intervals in the Windsor stratigraphy; (6) red, siliciclastic internal sediments present in some cavities; and (7) meteoric, gravitational calcite cement is associated with the internal sediments.

The late origin of the karstic breccia is supported by: (1) the presence of fragments of the synsedimentary breccia of the Macumber Formation; (2) the presence of siliciclastic and evaporite fragments that could only originate from higher up in the Windsor stratigraphy; (3) the presence, in Macumber fragments only, of late-stage burial calcite cement and solid bitumen; and (4) the presence of sideritized carbonate fragments in the Walton area. The age of this subaerial exposure is poorly constrained but is considered to be likely late Westphalian or younger (G. Lynch, personal communication, 1993).

The collapse karstic interpretation for the Pembroke breccia has been previously proposed (Clifton, 1967; Geldsetzer, 1977, 1978) but this interpretation was applied, by many subsequent geologists, for the entire brecciated interval of lower Windsor carbonates. Karstic collapse of basal Windsor carbonates indeed occurred but postdated synsedimentary brecciation of the Macumber. From underground information at Walton, the karstic breccia is post-sulfide ore as well (Burtt, 1995).

\section{Mineralization AND TECTONIC BRECCIA}

The relationships between base metal mineralizations and breccias in the lower part of the Windsor Group, the Gays River Formation excluded, are significant for exploration. Metallogenic studies for the Walton and Jubilee deposits have documented the association of the mineralization event with breccias (Burtt, 1995; Savard et al., in press). However, distinction between breccia types is critical because the late karstic breccia definitively post-dates ore emplacement and the erosive processes it is related to have locally removed portions of ore deposits (e.g., Walton). The synsedimentary breccia with its fine carbonate matrix constitutes a rather tight rock unit after compaction, except at Walton where early sideritization likely preserved some porosity. In the following section, brief information pertinent to the origin of the breccias is given.

\section{The Jubilee deposit}

Mineralization at Jubilee is found in a complex network of secondary porosity created by detachment-related, bedding-parallel tectonic movement and later vertical faulting. The ore-hosting breccia is exclusively found at the top of the Macumber Formation and has a generally flat distribution. The breccia consists of unsorted angular fragments of Macumber microbial mats with clasts having locally a jigsaw puzzle-like texture. The vertical fractures are post-breccia 

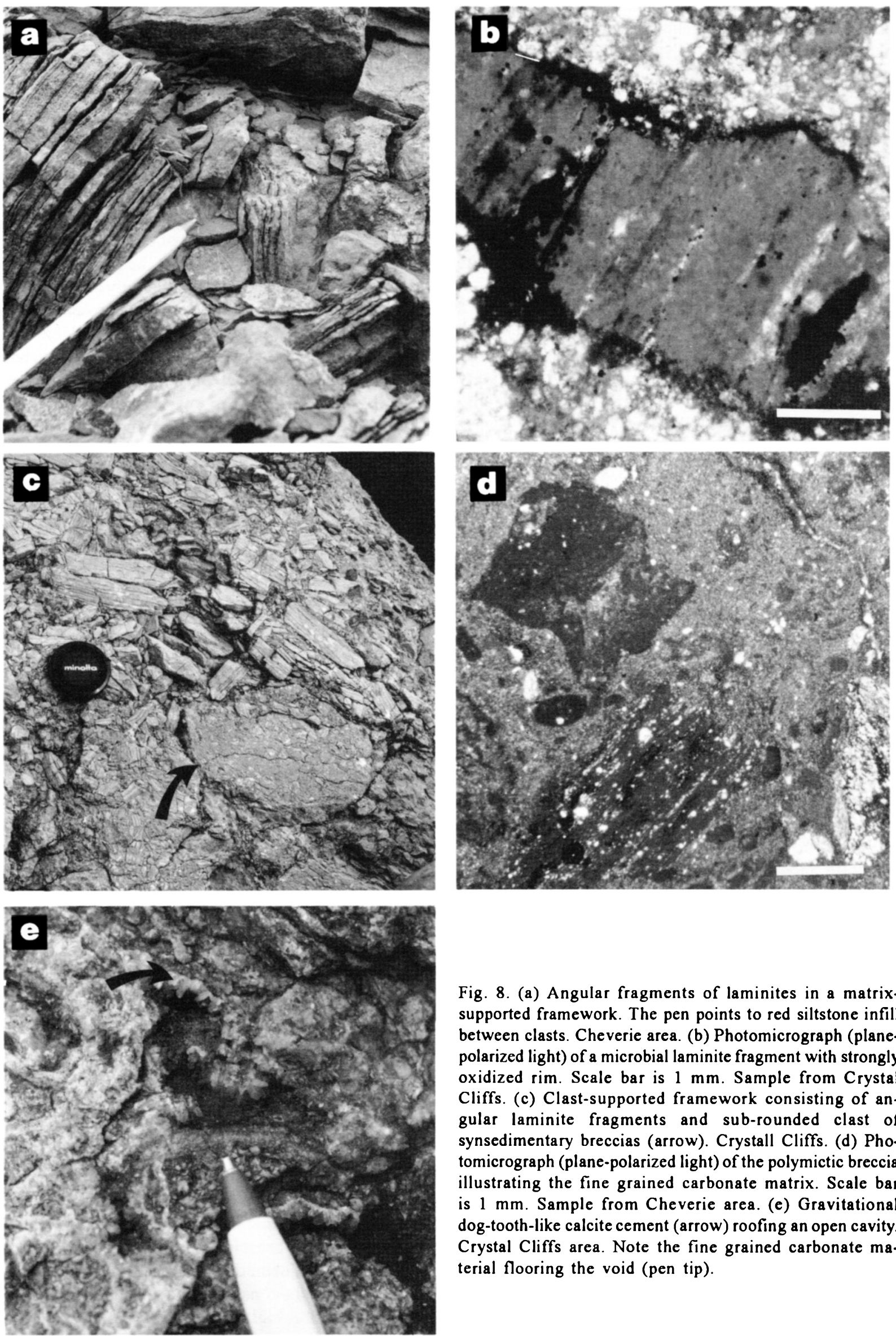

Fig. 8. (a) Angular fragments of laminites in a matrixsupported framework. The pen points to red siltstone infill between clasts. Cheverie area. (b) Photomicrograph (planepolarized light) of a microbial laminite fragment with strongly oxidized rim. Scale bar is $1 \mathrm{~mm}$. Sample from Crystal Cliffs. (c) Clast-supported framework consisting of angular laminite fragments and sub-rounded clast of synsedimentary breccias (arrow). Crystall Cliffs. (d) Photomicrograph (plane-polarized light) of the polymictic breccia illustrating the fine grained carbonate matrix. Scale bar is $1 \mathrm{~mm}$. Sample from Cheverie area. (e) Gravitational dog-tooth-like calcite cement (arrow) roofing an open cavity. Crystal Cliffs area. Note the fine grained carbonate material flooring the void (pen tip). 
and related to post-detachment, sub-vertical faulting (Fallara, 1995).

The inter-fragment pores were filled by a hydrocarbonrich, isopachous fibrous calcite of relatively low temperature $\left(\approx 70^{\circ} \mathrm{C}\right)$ and salinity ( $25 \mathrm{wt} . \%$ eq. $\left.\mathrm{NaCl}\right)$, followed by post-vertical fracture mineralization and syn- to post-ore, high temperature $\left(150-220^{\circ} \mathrm{C}\right)$ anhedral calcite cement (Chi et al., 1995). The similarities in textural characteristics (clasts, cements, jigsaw puzzle fabric), stratigraphic position and geometry of the Jubilee mineralized breccia with the tectonic breccia at Aulds Cove and other areas along the Ainslie Detachment zone are clear; brecciation played a key role in ground preparation at Jubilee.

\section{The Walton deposit}

The Walton area offers two types of breccias; the synsedimentary and the late karstic ones, and the relative chronology of these events can be easily documented. Mineralization has recently been divided into two types, depending on the presence or absence of barite in the ore (Burtt, 1995). The dominant type (either $\mathrm{Cu}$ - or $\mathrm{Pb}$-rich; Burtt, 1995) is associated with significant amounts of barite; it occurs as a massive replacement of both the Macumber microbial mats and synsedimentary breccias (the Pembroke siderite of previous workers). The geometry of the ore body (thickening where the synsedimentary breccia is thicker) suggests a key role for the synsedimentary breccia in enhancing the volume of the host-rock. It seems reasonable to suggest that the small-scale porosity of the synsedimentary breccia, preserved by early sideritization, helped in localizing fluid flow. Elsewhere in the structural basin hosting the Walton deposit, the synsedimentary breccia is absent and mineralization is negligible (Burtt, 1995). However, it is significant that in other structural basins in Nova Scotia, the synsedimentary breccia is present but not mineralized.

\section{Conclusions}

The Macumber Formation and Pembroke unit occur in the lower part of the Windsor Group; they have been, over the years, the subject of much debate. A proper identification of the different breccias is important with regards to mineralization since various base metal occurrences are spatially associated with some of the breccias.

Based on sedimentologic and diagenetic criteria, three types of breccias are recognized: (1) an early synsedimentary breccia related to slope failure (middle Viséan); (2) tectonic breccias related principally to the Ainslie Detachment and to late sub-vertical faulting along the detachment zone (Namurian-Westphalian); and (3) a karstic breccia (Pembroke sensu stricto) related to late subaerial exposure of the succession (latest Westphalian or younger). Table 1 summarizes the main characteristics that have been used (1) to

Table 1. Main characteristics of basal Windsor carbonate breccias

\begin{tabular}{|c|c|c|c|}
\hline & $\begin{array}{c}\text { EARLY } \\
\text { Synsedimentary }\end{array}$ & LATE & Karstic \\
\hline$\%$ clasts & $60-95 \%$ & $40-75 \%$ & $40-90 \%$ \\
\hline Nature & Laminite & Laminite & $\begin{array}{l}\text { Laminite, breccia, red mudstone, } \\
\text { various siliciclastics } \\
\text { (+ siderite: Walton) }\end{array}$ \\
\hline Rounding & Some & None & Some for mudstone \\
\hline Size & $<1 \mathrm{~mm}$ to $10 \mathrm{~cm}$ & $<1 \mathrm{~mm}$ to $5 \mathrm{~cm}$ & $1 \mathrm{~mm}$ to $50 \mathrm{~cm}$ \\
\hline $\begin{array}{l}\text { Matrix } \\
\text { cement }\end{array}$ & $\begin{array}{l}\text { Crushed frg. } \\
\text { and lime mud }\end{array}$ & $\begin{array}{l}\text { Crushed frg. } \\
\text { and fibrous } \\
\text { calcite cement }\end{array}$ & $\begin{array}{l}\text { Carbonate frg, red siliciclastic, } \\
\text { lime mud, calcite cement }\end{array}$ \\
\hline $\begin{array}{l}\text { Sedimentary } \\
\text { structures }\end{array}$ & $\begin{array}{l}\text { Soft-sediment } \\
\text { deformation, } \\
\text { Concave-up shear } \\
\text { failure planes, } \\
\text { Cyclic pattern }\end{array}$ & $\begin{array}{l}\text { Jigsaw puzzle- } \\
\text { like texture }\end{array}$ & $\begin{array}{l}\text { Coarsening- and fining- } \\
\text { upward, graded matrix }\end{array}$ \\
\hline $\begin{array}{l}\text { Diagenetic } \\
\text { elements }\end{array}$ & $\begin{array}{l}\text { Pre-stylolite. } \\
\text { Prior to } \\
\text { secondary } \\
\text { dissolution }\end{array}$ & $\begin{array}{l}\text { Post-secondary } \\
\text { dissolution } \\
\text { (Aulds Cove) }\end{array}$ & $\begin{array}{l}\text { Dissolution surfaces on clasts } \\
\text { Oxidized rims and matrix, } \\
\text { Post-stylolite (post-siderite: } \\
\text { Walton) and post-sulphides }\end{array}$ \\
\hline $\begin{array}{l}\text { Timing of } \\
\text { formation }\end{array}$ & $\begin{array}{l}\text { Pre-burial and } \\
\text { hydrocarbon mi- } \\
\text { gration } \\
\text { MIDDLE VISÉAN }\end{array}$ & $\begin{array}{l}\text { Syn-burial and } \\
\text { hydrocarbon mi- } \\
\text { gration (locally) } \\
\text { NAMURIAN- } \\
\text { WESTPHALIAN (?) }\end{array}$ & $\begin{array}{l}\text { Post-burial and other breccias } \\
\text { WESTPHALIAN OR YOUNGER (?) }\end{array}$ \\
\hline Unit & MACUMBER & MACUMBER & PEMBROKE (sensu stricto) \\
\hline
\end{tabular}


distinguish between these breccias, and (2) to propose possible formation mechanisms. The synsedimentary and tectonic breccias are considered to belong to the Macumber Formation, whereas the informal Pembroke designation is applied to the late karstic breccia.

The metallogenic significance of distinguishing between the breccias lies in the fact that the synsedimentary breccia is pre-ore, whereas the karst breccia is post-ore. The mineralization at the Jubilee deposit is encased in a tectonic breccia that can be associated with the Ainslie Detachment. Conversely, even though some mineralization at the Walton deposit is of vein-type (Burtt, 1995), the mineralization of the main ore body seems to have been controlled (in its distribution and origin) by the presence of a thick succession of sideritized synsedimentary breccia.

\section{ACKNOWLEDGEMENTS}

This study is supported by Canada-Nova Scotia Cooperation Agreement on Mineral Development and directly funded by the Magdalen Basin NATMAP project. The authors wish to express their deepest gratitude to the staff of the Nova Scotia Department of Natural Resources Core Library in Stellarton, Nova Scotia. Thanks are extended to G. Lynch who reviewed an earlier draft of the manuscript. The manuscript has benefited from detailed comments and fine suggestions of Atlantic Geology reviewers H.H.J. Geldsetzer and R.C. Boehner.

Basal Windsor Working Group. 1994. Fluid migration and mineralization in the Lower Windsor Group. In Program and Summaries, Eighteenth annual review of activities. Edited by D.R. MacDonald. Nova Scotia Department of Natural Resources, Mines and Energy Branches, Report 94-2, pp. 45-57.

Bastin, E.S. and Williams, H.S. 1914. Description of the Eastport quadrangle, Maine. United States Geological Survey, Geological Atlas, Eastport Folio 192, 15 p.

Boehner, R.C., Giles, P.S., Murray, D.A., and Ryan, R.J. 1989. Carbonate buildups of the Gays River Formation, Lower Carboniferous Windsor Group, Nova Scotia. In Reefs, Canada and adjacent areas. Edited by H.H.J. Geldsetzer, N.P. James and G.E. Tebbutt. Canadian Society of Petroleum Geologists, Memoir 13, pp. 609-621.

BurTt, M.D. 1995. Geology of the B-baseline zone, Walton Ba$\mathrm{Cu}-\mathrm{Pb}-\mathrm{Zn}-\mathrm{Ag}$ deposit, Nova Scotia. Unpublished M.Sc. thesis, Ottawa-Carleton Geoscience Centre, Ottawa, 117 p.

Chi, G., Savard, M.M., and Héroux, Y. 1995. Constraints from fluid inclusion data on the origin of the Jubilee $\mathrm{Zn}-\mathrm{Pb}$ deposit, Nova Scotia. The Canadian Mineralogist, 33, Part 4, pp. 709-721.

Clifton, H.E. 1967. Solution-collapse and cavity filling in the Windsor Group, Nova-Scotia, Canada. Bulletin of the Geological Society of America, 78, pp. 819-832.

Cook, H.E. and Muluins, H.T. 1983. Basin Margin. In Carbonate depositional environments. Edited by P.A. Scholle, D.G. Bebout and C.H. Moore. American Association of Petroleum Geologists, Memoir 33, pp. 539-617.

Fallara, F. 1995. Pétrographie, géochimie et métallogénie de l'indice de $\mathrm{Pb}-\mathrm{Zn}$ de Jubilee à l'ile du Cap Breton en Nouvelle Ecosse. Unpublished M.Sc. thesis, INRS-Géoressources, SteFoy.
Fallara, F., Savard, M.M., Lynch, G., and Paradis, S. 1994. Preliminary geological and geochemical results characterizing the mineralization processes in the Jubilee $\mathrm{Pb}-\mathrm{Zn}$ deposit, Cape Breton Island, Nova Scotia. In Current Research, 1994-D, Geological Survey of Canada, pp. 63-71

Geldsetzer, H.H.J. 1977. The Windsor Group of Cape Breton Island, Nova Scotia. In Report of Activities, Part A, Geological Survey of Canada, Paper 77-1A, pp. 425-428.

.... 1978. The Windsor Group in Atlantic Canada - an update. In Current Research, Part C, Geological Survey of Canada, Paper 78-1C, pp. 43-48.

GiLES, P.S. 1981. Major transgressive-regressive cycles in Middle to Late Visean rocks of Nova Scotia. Nova Scotia Department of Mines and Energy, Paper 81-2.

Giles, P.S. and LyNCH, G. 1994. Stratigraphic omission across the Ainslie Detachment in east-central Nova Scotia. In Current Research, 1994-D, Geological Survey of Canada, pp. 8994.

Giles, P.S., Hein, F.J., and Allen, T.L. 1995. Late Devonian and Carboniferous history of Western Cape Breton Island. Atlantic Geoscience Society Annual Colloquium, St. Francis Xavier University, Program with Abstracts, p. 13.

Hamblin, A.P. and Rust, B.R. 1989. Tectono-sedimentary analysis of alternate-polarity half-graben basin-fill successions: Late Devonian-Early Devonian Carboniferous Horton Group, Cape Breton Island, Nova Scotia. Basin Research, 2, pp. 239-255

Hein, F.J., Graves, M.C., and Ruffman, A. 1993. The Jubilee $\mathrm{Zn}-\mathrm{Pb}$ deposit, Nova Scotia: the role of synsedimentary faults. In Mineral Deposit Studies in Nova Scotia, Volume 2. Edited by A.L. Sangster. Geological Survey of Canada, Paper 91-9, pp. 49-69.

LAvole, D. 1994. Lithology and preliminary paleoenvironmental interpretation of the Macumber and Pembroke formations (Windsor Group, Early Carboniferous), Nova Scotia. In Current Research, 1994-D, Geological Survey of Canada, pp. 79. 88.

Lavoie, D. and Sangster, D.F. 1995. Origins and timing of basal Windsor carbonate breccias, Nova Scotia. In Current Research, 1995-D, Geological Survey of Canada, pp. 1-10.

Lavoie, D. and Savard, M.M. 1995. The Early Carboniferous Macumber Formation of the Magdalen Basin, Nova Scotia: Back to the deep-water microbial laminites. Geological Association of Canada - Mineralogical Association of Canada, 1995 Joint Annual Meeting, Victoria. Program with Abstracts, p. A56.

LyNCH, G. and GILES, P.S. 1993. Extensional tectonics and evolution of the Upper Devonian-Carboniferous Maritimes Basin, Nova Scotia. Geological Association of Canada - Mineralogical Association of Canada, 1993 Joint Annual Meeting, Edmonton. Program with Abstracts, p. A-62.

Lynch, G. and Tremblay, C. 1994. Late Devonian-Carboniferous detachment faulting and extensional tectonics in western Cape Breton Island, Nova Scotia, Canada. Tectonophysics, 238, pp. 55-69.

Paradis, S., Savard, M.M., and Fallara, F. 1993. Preliminary study on diagenesis and mineralization of the Jubilee $\mathrm{Pb}$ Zn deposit, Nova Scotia. In Current Research, 1993-D, Geological Survey of Canada, pp. 111-119.

SAGE, N.M. 1954. The stratigraphy of the Windsor Group in the Antigonish quadrangles and Mahone Bay-St. Margarets Bay area, Nova Scotia. Nova Scotia Department of Mines, Memoir 3.

Savard, M.M., Lynch, G., and Fallara, F. In press. Burial diagenesis model for the Macumber Formation on Cape Breton 
Island - Implications for the tectonic evolution of the Windsor Group. Atlantic Geology, 32.

SCHENK, P.E. 1967. The Macumber Formation of the Maritimes Provinces - a Mississippian analogue to Recent strand-line carbonates of the Persian Gulf. Journal of Sedimentary Petrology, 37, pp. 365-376.

SChenk, P.E., von Bitter, P.H., and Matsumoto, R. 1992. A lacustrine origin for the Basal Windsor/Codroy Groups (Carboniferous) of Atlantic Canada - Introducing Loch Macumber! Geological Association of Canada - Mineralogical Association of Canada, 1992 Joint Annual Meeting, Wolfville. Program with Abstracts, p. A-99.

---- 1994. Deep-basin/deep-water carbonate-evaporite deposition of a saline giant: Loch Macumber (Viséan), Atlantic Canada. Carbonates and Evaporites, 9, pp. 187-210.

S MITH, L. and Collins, J.A. 1979. Unconformities, sedimentary copper mineralization, and thrust faulting in the Horton and Windsor groups, Cape Breton Island and central Nova Scotia. Neuvième Congrès International de stratigraphie et de Géologie du Carbonifère, Washington and Champaign-Urbana, 3, Southern Illinois University Press, pp. 105-116.
Stevenson, I.M. 1958. Truro map-area, Colchester and Hants counties, Nova Scotia. Geological Survey of Canada, Memoir 297, 124 p.

Tobey, E.D., McConnell, M., Schenk, P.E., and von Bitter, P.H. 1995. Carbonate microbial mounds, mineralized vents, periplatformal oozes, and slump domes in Macumber equivalents, Eastern Cape Breton. Atlantic Geoscience Society Annual Meeting, St. Francis Xavier University, Program with Abstracts, p. 28.

von Bitter, P.H., Scott, S.D., and Schenk, P.E. 1992. Chemosynthesis: An alternate hypothesis for Carboniferous biotas in bryozoan/microbial mounds, Newfoundland, Canada. Palaios, 7, pp. 466-484.

Weeks, L.J. 1948. Londonderry and Bass River map-areas, Colchester and Hants Counties, Nova Scotia. Geological Survey of Canada, Memoir 245, 86 p.

Editorial Responsibility: P. Giles and G.L. Williams 